\title{
Manajemen Program Siaran Suara Persada, Radio Persada FM Dalam Mempertahankan Eksistensi di Era Digitalisasi
}

\author{
Management of the Siaran Sura Persada Program, Radio Persada FM \\ In Maintaining Existence in the Era of Digitalization
}

\author{
Yefi Dyan Nofa Harumike ${ }^{1}$, Endah Siswati ${ }^{2}$, Fera Tara Batari ${ }^{3}$ \\ Fakultas Ilmu Sosial dan Ilmu Politik, Univ. Islam Balitar \\ Jl. Majapahit No. 2 - 4, Blitar, Indonesia \\ E-mail: yefidnh@gmail.com
}

\begin{abstract}
ABSTRAK
Radio adalah salah satu media komunikasi yang dulu pernah menjadi primadona dalam masyarakat. Namun seiring pesatnya perkembangan tehnologi media, radio menjadi berkurang daya tariknya. Radio harus berjuang untuk mempertahankan eksistensinya di tengah masyarakat media. Bermacam upaya dilakukan radio untuk merebut kembali hati pendengarnya melalui pembenahan kualitas penyiaran hingga pembaharuan, peningkatan dan pengembangan program. Radio Persada menghadapi persoalan yang sama. Radio Persada merupakan Lembaga Penyiaran Publik Lokal (LPPL) di Kabupaten Blitar yang bersifat independen, netral, dan tidak komersial. Radio ini memproduksi program siaran tidak semata-mata untuk memenuhi tuntutan liberalisasi, selera pasar, atau corong pemerintah, tetapi terutama untuk menjalankan fungsinya sebagai media massa yang melayani kepentingan masyarakat. Program Siaran Suara Persada adalah program unggulan Radio Persada yang berupaya mewujudkan fungsi pelayanan tersebut. Program yang kontennya mengutamakan informasi atau berita lokal dan reportase langsung ini disiarkan sejak tahun 2018 dan tetap eksis hingga saat ini. Penelitian ini bertujuan mendalami manajemen Program Siaran Suara Persada dalam upaya Radio Persada mempertahankan eksistensinya di era digitalisasi. Penelitian dilakukan dengan menggunakan metode kualitatif dengan teknik pengumpulan data melalui wawancara, observasi serta studi dokumentasi. Penelitian ini menemukan beberapa faktor yang mempengaruhi eksistensi Program Suara Persada, yaitu; 1) keunggulan pada konten local yang dikemas serius tetapi santai, 2) pelibatan masyarakat melalui program citizen journalism dalam program Suara Persada, 3) penerapan manajemen program yang mengikuti perkembangan zaman dalam semua tahapan kegiatan planning, organizing, influencing dan controling, 4) penggunaan saluran streaming serta pemanfaatan media sosial Facebook dan Instagram, 5) konsistensi dalam mempertahankan sistem komunikasi dua arah menggunakan berbagai media komunikasi termasuk media sosial.
\end{abstract}

Kata Kunci: Radio, Manajemen Program, Eksistensi, Digitalisasi, Jurnalisme Warga. 


\begin{abstract}
Radio is one of the communication media that used to be a primadonna in society. However as media technology grew rapidly, radio became less attractive. Radio had to fight to maintain its existence in the media community. Various efforts are made by radio to reclaim the hearts of its listeners through improving the quality of broadcasting until the renewal, improvement and development of the program. Radio Persada faces the same problem. Radio Persada is a Local Public Broadcasting Institution (LPPL) in Blitar Regency that is independent, neutral, and non-commercial. It produces broadcast programs not solely to meet the demands of capitalism, liberalism, market tastes, or government mouthpiece, but primarily to carry out its function as a mass media serving the interests of the public. Persada is the flagship program of Radio Persada that seeks to realize the function of the service. Programs whose content prioritizes local information or news and live reportage is broadcast since 2018 and still exists today. This research aims to understand the management of Suara Persada program in an effort to maintain its existence in the era of digitization. Research is conducted using qualitative methods with data collection techniques through interviews, observations and documentation studies. This research found several faktors that influence the existence of Suara Persada program, namely; 1) excellence in serious but relaxing packaged local content, 2) community engagement through citizen journalism in Suara Persada program, 3) implementation of program management that follows developments in all stages of planning, organizing, influencing and controling activities, 4) the use of streaming channels and the utilization of social media (Facebook and Instagram), 5) consistency in maintaining a two-way communication system using various communication media including social media.
\end{abstract}

Keywords : Radio, Program Management, Existence, Digitization, Citizen Journalism.

\title{
PENDAHULUAN
}

Manusia adalah makhluk sosial (Bungin, 2007). Setiap manusia berhubungan dengan manusia lainnya dan tidak lepas dari kegiatan komunikasi, baik secara verbal maupun non verbal, internal maupun eksternal (Rahmat, 2007). Komunikasi memungkinkan terjadinya interaksi antar manusia (Bungin, 2007). Manusia berkomunikasi secara langsung dan tidak langsung menggunakan media yang sekarang ini sangat beragam bentuknya. Perkembangan tehnologi dan meningkatnya kebutuhan informasi ikut mempengaruhi perkembangan media komunikasi (Bungin, 2007).

Media komunikasi tumbuh dengan pesat, jarak dan waktu tidak lagi menjadi hambatan untuk melakukan komunikasi. Apalagi dengan munculnya jaringan internet, manusia semakin dimudahkan dalam berkomunikasi maupun dalam mengakses informasi. Di tengah maraknya media komunikasi baru yang muncul 
seiring dengan perkembangan tehnologi informasi, media komunikasi massa elektronik yang pernah menjadi primadona di masa lampau seperti radio, menghadapi tantangan yang cukup berat untuk tetap eksis dan mendapat tempat di hati masyarakat. Radio harus berjuang untuk dapat bertahan dan tidak digeser oleh media lainnya. Berbagai upaya dilakukan radio untuk menjaga eksistensinya mulai dengan membenahi kualitas penyiaran, sumber daya, sampai dengan perombakan dan pengembangan program acara yang dimilikinya (Masduki, 2001). Radio dituntut untuk terus update dengan segala sesuatu yang dibutuhkan oleh masyarakat (Riswandi, 2009).

Radio Persada menghadapi tantangan yang sama, terlebih sebagai Lembaga Penyiaran Publik Lokal (LPPL), Radio Persada juga memiliki tanggung jawab, tugas pokok dan fungsi tersendiri. Radio Persada tidak hanya sebagai media hiburan, namun juga sebagai media informasi yang menjadi perpanjangan tangan pihak pemerintah Kabupaten Blitar.

Berdasarkan latar belakang tersebut penulis ingin mendalami bagaimana Radio Persada menjalankan manajemen dalam mengemas program acara dalam upayanya mempertahankan eksistensi di era digitalisasi. Dalam hal ini penulis akan memfokuskan perhatian pada managemen program siaran Suara Persada yang terbukti tetap eksis hingga sekarang sejak disiarkan pertama kali pada tahun 2018 dan bahkan kemudian menjadi program acara unggulan.

Setiap organisasi maupun lembaga memiliki struktur manajemen dalam menjalankan kegiatan-kegiatannya, begitu pula dengan media massa radio. Manajemen sendiri merupakan suatu proses pengelolaan yang memiliki tugas dan tanggung jawab terhadap keberhasilan dan tercapainya tujuan lembaga atau kegiatan (Morissan, 2009). George R. Terry dalam Malayu (1990) mendefinisikan manajemen sebagai suatu proses yang terdiri dari tindakan-tindakan perencanaan, pengorganisasian, penggerakan dan pengawasan, yang dilakukan untuk menentukan serta mencapai sasaran yang telah ditentukan melalui pemanfaatan sumber daya manusia dan sumber-sumber lainnya.

Sumber daya manusia yang ada di suatu media penyiaran terbagi dalam beberapa divisi, masing-masing divisi memiliki tugas dan tanggung jawab yang berbeda. Begitu juga dengan tugas dan tanggung jawab terkait dengan pemilihan 
media penyiaran untuk mengikuti arus globalisasi terkait dengan digitalisasi. Setiap media penyiaran yang ingin terus eksis di udara, harus mampu mempertahankan eksistensi dengan melakukan update peralatan siaran dan media pendukung lainnya (Mufid, 2005).

Manajemen di lembaga penyiaran yang dilakukan oleh sumber daya manusia (SDM) yang berada di dalamnya, memiliki peran penting dalam melakukan kegiatan perencanaan, pengorganisasian hingga pengawasan dalam menjaga eksistensi suatu program. Terobosan dan inovasi sangat diperlukan di era digitalisasi saat ini.

Dalam kehidupan masyarakat sosial, masing-masing individu memiliki akses media yang berbeda untuk memenuhi kebutuhan informasi. Salah satu media komunikasi massa elektronik yang tetap memiliki tempat di hati masyarakat adalah radio. Radio merupakan media massa elektronik tertua sebelum munculnya media massa televisi. Radio menggunakan lambang komunikasi berbunyi atau audio. Prilani (2010) mengatakan bahwa radio adalah media untuk orang perorang dan untuk saat ini radio adalah tentang manusia, berfokus pada bahasa lisan dan bunyi suara manusia dan mengarahkannya secara terus-menerus kepada berbagai kisah dari sudut pandang manusia. Seorang penyiar bisa mengurangi perasaan kesepian pendengar sambil menciptakan rasa persahabatan. Sementara Oramahi (2012) menyebut radio sebagai salah satu jenis media massa yang digunakan sebagai salah satu media informasi, edukasi, dan hiburan bagi masyarakat.

Program atau dalam bahasa Inggris "programme” memiliki pengertian acara atau rencana. Program merupakan serangkaian kegiatan yang disiarkan oleh media massa radio untuk pemenuhan informasi, hiburan dan edukasi bagi masyarakat (Morissan, 2009). Suatu program siaran memiliki target audiens masing-masing dan terencana. Kegiatan program siaran, tidak lepas dari pertimbangan dan persiapan sehingga sampai dengan ke ruang dengar masayarakat (Morissan, 2009).

Dalam melakukan perencanaan program siaran radio, pengelola perlu memperhatikan produk, price atau biaya, place atau tempat dan promosi. Produk berkaitan dengan materi program yang dipilih yang harus disesuaikan dengan target bidik audiens. Price atau biaya harus menjadi pertimbangan penting dalam pembuatan program. Selanjutnya place memperhitungkan apakah sebuah program 
siaran tertentu diudarakan pada waktu dan keadaan yang tepat oleh pengelola program, sesuai dengan kebutuhan dan keinginan audien. Ketepatan ini sangat mempengaruhi keberhasilan suatu program siaran. Yang terakhir adalah promotion: untuk memberikan informasi atau memperkenalkan suatu program siaran kepada audien serta para pemasang iklan untuk terjalinnya kerjasama. Promotion merupakan kegiatan yang efektif untuk mendukung keberhasilan program (Morissan, 2009).

Program siaran radio merupakan sajian yang berbentuk audio. Dalam penyampaian program siaran radio, penyiar dituntut untuk dapat membangun ruang imajiner pendengarnya. Bahasa yang digunakan disebut dengan bahasa tutur. Bahasa tutur adalah pola bicara yang seolah-olah penyiar sedang melakukan obrolan ke masing-masing individu atau pendengar. Penggunaan bahasa tutur merupakan kekuatan dari sebuah program siaran radio dalam melayani pendengar (Riswandi, 2009). Program siaran radio memiliki jenis dan segmentasi yang beragam. Jenis program siaran radio diantaranya berita, hiburan, infotainment, talk show, dialog interaktif, dsb (Riswandi, 2009).

Makna dari kata digitalisasi menurut KKBI (Kamus Besar Bahasa Indonesia) adalah proses pemberian atau pemakaian sistem digital (kbbi.web.id). Digitalisasi merupakan proses alih media dari bentuk tercetak, audio, maupun video menjadi bentuk digital. Digitalisasi juga berfungsi sebagai dokumentasi atau arsip dokumen dengan bentuk digital maupun perpustakaan digital. Saat ini segala lini kehidupan sedang dalam masa peralihan atau migrasi terkait dengan teknologi digital. Digitalisasi ini bertujuan untuk mencapai efisiensi dan optimalisasi dalam segala kegiatan manusia.

Sosial media atau media sosial merupakan suatu wadah bagi setiap orang yang memiliki akses internet (online) untuk melakukan kegiatan sosial mereka melalui daring. Setiap orang yang menggunakan fasilitas media sosial maka memiliki kesempatan yang tidak terbatas dalam akses informasi, mengelola informasi, dan menyebarkan informasi (Masduki, 2001).

Media sosial merupakan media komunikasi yang tidak terbatas baik secara ruang maupun waktu. Kapan dan dimanapun seseorang akan memperoleh kesempatan yang sama dalam hal informasi dan komunikasi. 
Bentuk-bentuk sosial media yang sering digunakan oleh banyak orang diantaranya Facebook, Instagram, WhatsApp, dan Twitter. Seseorang yang memiliki smartphone dengan akses internet (online), dapat dengan mudah memanfaatkan berbagai jenis sosial media.

Selain sebagai alat komunikasi pribadi, media sosial juga dipergunakan oleh berbagai kalangan dalam hal bisnis maupun akses pelayanan publik. Dalam bidang bisnis, seseorang bisa dengan mudah menginformasikan produk baik barang atau jasa dengan tujuan pemasaran melalui media sosial. Begitu juga dengan pelayanan publik, media sosial akan dapat mengakomodir segala informasi yang disampaikan kepada masyarakat. (Masduki, 2001).

Menurut KKBI (Kamus Besar Bahasa Indonesia) eksistensi memiliki arti berada atau keberadaan (kbbi.web.id). Keberadaan suatu program acara atau eksistensi dari sebuah program siaran dipengaruhi oleh banyak faktor. Di antara faktor-faktor yang mempengaruhi eksistensi program siaran adalah persoalan manajemen program acara dan pemanfaatan media sosial untuk mendukung program on-air. (Morissan, 2009). Berikut ini adalah kerangka pemikiran yang sekaligus menggambarkan alur penelitian untuk memandu peneliti menjalankan penelitian sesuai dengan tujuan penelitian yang telah direncanakan.

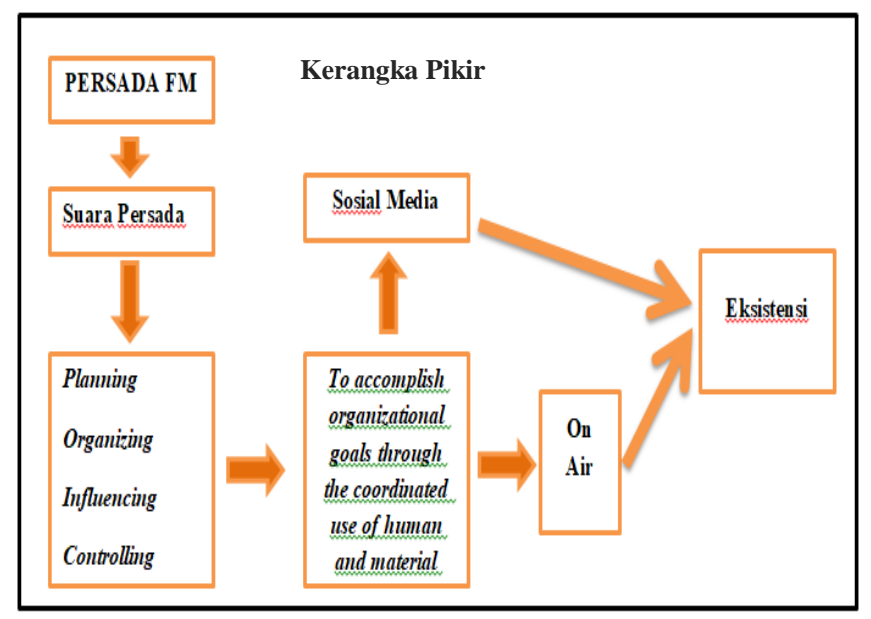

Sumber: Diolah oleh peneliti

\section{METODE PENELITIAN}

Selaras dengan permasalahan yang dikaji, penelitian ini menggunakan metode kualitatif. Data dikumpulkan melalui wawancara mendalam, observasi dan 
studi dokumentasi. Dalam proses wawancara dan observasi peneliti mengumpulkan data terkait dengan proses perencanaan, pengorganisasian, pengarahan dan pengawasan program siaran Suara Persada yang dilakukan oleh Radio Persada FM. Wawancara dilakukan dengan bagian programmer, dan kepala bagian penyiaran sebagai pihak yang dinilai paling kompeten dan memahami persoalan yang diteliti. Studi dokumentasi dilakukan untuk mendapatkan data pendukung dan pelengkap lainnya. Data-data penelitian dianalisis dengan menggunakan tehnik analisis data kualitatif Miles Huberman dan melalui tahap-tahap pengumpulan data, reduksi data, penyajian data dan penarikan kesimpulan (Miles \& Huberman, 2004). Sementara validasi data dilakukan dengan melakukan uji triangulasi sumber dan metode (Moleong, 1996).

\section{HASIL DAN PEMBAHASAN}

\section{Profil Radio Persada FM}

Pemerintah Kabupaten Blitar, memiliki komitmen untuk menyebarluaskan informasi pendidikan, kebudayaan, dan hiburan yang sehat bagi masyarakat dan memenuhi hak-hak masyarakat akan kebutuhan informasi yang benar, jelas, transparan, bertanggungjawab. Pemerintah Kabupaten Blitar juga memberikan kesempatan pada masyarakat untuk menyampaikan pendapat, pandangan dan aspirasi. Dengan demikian, warga masyarakat diposisikan sebagai subyek dan dilindungi haknya dalam memperoleh informasi, dan tidak diposisikan hanya sebagai obyek sebuah industri media penyiaran semata. Untuk itu pemerintah daerah membentuk Lembaga Penyiaran Publik Lokal (LPPL),

Pendirian dan penyelenggaraan Radio Persada FM didasarkan pada dua payung hukum yaitu Peraturan Pemerintah Daerah Kabupaten Blitar, Nomor: 2 Tahun 2010 tentang Lembaga Penyiaran Publik Lokal (LPPL) Radio Persada FM dan Perda No. 20 Tahun 2012. Radio Persada FM berada di frekuensi 87,6 Mhz dan berlokasi di Jalan Kota Baru Kanigoro RT 02 RW 08 Kabupaten Blitar. Dewan pengawas LPPL Persada FM terdiri dari unsur media massa, masyarakat, dan pemerintah Kabupaten Blitar. Direktur utama adalah salah seorang dari tiga dewan direksi yang telah ditetapkan oleh dewan pengawas. 
Visi radio Persada FM adalah sebagai sumber informasi yang terpercaya, netral dan juga sebagai media pendidikan, hiburan serta pelestari budaya. Secara umum radio Persada FM memiliki spirit, meningkatkan kepuasan dan kepercayaan pendengar, meningkatkan kapabilitas SDM, serta terciptanya proses inovasi yang dapat menimbulkan kepercayaan dan kepuasan pengiklan dan pendengar.

Radio Persada FM sebagai LPPL bersifat independen, netral, tidak komersial. Radio ini memproduksi program siaran tidak didasarkan pada tuntutan kapitalisme, liberalisme dan selera pasar serta tidak juga semata-mata sebagai corong pemerintah. Produksi program acara utamanya didasarkan pada pertimbangan radio sebagai media yang berfungsi memberikan pelayanan untuk kepentingan masyarakat.

\section{Program Acara Suara Persada}

Program siaran Suara Persada telah disiarkan sejak tahun 2018 dan mengudara mulai pukul 06.00 s.d 17.00 WIB. Muatan utama program Suara Persada adalah informasi dan berita lokal serta reportase secara langsung. Radio Persada menjadi sebuah radio yang dibutuhkan masyarakat karena memilili nilai proximity (kedekatan). Berita akan dianggap lebih penting jika berita tersebut terjadi di daerah yang dekat dengan pendengarnya. Oleh karena itu, informasi dari berita tersebut akan semakin berguna bagi pendengar (Kusumaningrat, $2005: 62$ ). Durasi siaran program Suara Persada sangat panjang dan hal itu dimaksudkan untuk memberikan informasi lebih lengkap kepada masyarakat. Radio Persada juga menyelipkan program citizen journalism pada acara Suara Persada sehingga memungkinkan masyarakat berkontribusi memberikan informasi kepada masyarakat dan tidak hanya menjadi pendengar atau penerima informasi saja. Dengan turut andil mengumpulkan dan membagikan informasi, masyarakat akan semakin merasa dibutuhkan sehingga rasa saling memiliki antara masyarakat dan radio akan semakin dapat terbentuk (Andayani, 2017 : 141).

Pemberitaan dalam program Suara Persada dibagi menjadi beberapa bagian sebagaimana tercantum pada bagan berikut ini:

Tabel 1 Program Suara Persada

\begin{tabular}{|l|c|c|c|}
\hline \multicolumn{4}{|l|}{ Program Rutin Selama Seminggu } \\
\hline No. & Program Acara & Waktu & Keterangan \\
\hline
\end{tabular}




\begin{tabular}{|c|c|c|c|}
\hline 1. & Paket Berita Buletin Pagi & $06.00-07.00$ & $\begin{array}{l}\text { Berisi berita terbaru di pagi itu dan } \\
\text { kabar pasar. }\end{array}$ \\
\hline 2. & Informasi Berita Lengkap & $07.00-17.00$ & $\begin{array}{l}\text { Flash news yang disiarkan } 1 \text { jam sekali } \\
\text { dan berita lintas Jawa Timur setiap } 30 \\
\text { menit. }\end{array}$ \\
\hline 3. & Music Random Retro & $06.00-09.00$ & Berisi lagu retro yang diputar acak \\
\hline 4. & Oldiest Easy Listening & $09.00-12.00$ & Berisi lagu dari tahun 80 -an \\
\hline 5. & Dangdut Konvensional & $12.00-15.00$ & Lagu dangdut tradisional \\
\hline 6. & Dangdut Koplo & $15.00-17.00$ & Berisi lagu dangdut koplo \\
\hline \multicolumn{4}{|c|}{ Program Sepesial } \\
\hline 1. & Hallo Bupati (Dialog Rutin) & $\begin{array}{l}\text { Selasa } \\
06.00-07.00\end{array}$ & Dialog dengan Bupati Blitar \\
\hline 2. & Dialog Coffe Break & $\begin{array}{l}\text { Rabu } \\
10.00-11.00\end{array}$ & $\begin{array}{l}\text { Berisi dialog dengan anggota komunitas } \\
\text { pemuda di Blitar }\end{array}$ \\
\hline 3. & Hallo Polisi & $\begin{array}{l}\text { Kamis } \\
10.00-11.00\end{array}$ & Dialog dengan polisi \\
\hline 4. & $\begin{array}{l}\text { Dialog Forum Kesehatan Ibu } \\
\text { dan Anak }\end{array}$ & $\begin{array}{l}\text { Kamis } \\
\text { (Minggu ke-3) } \\
08.00-09.00 \\
\end{array}$ & $\begin{array}{l}\text { Dialog dengan anggota komunitas di } \\
\text { Blitar }\end{array}$ \\
\hline 5. & Dialog Granat & $\begin{array}{l}\text { Jumat (Minggu } \\
\text { ke-3) } \\
10.00-11.00\end{array}$ & \\
\hline
\end{tabular}

Sumber: Diolah oleh peneliti

\section{Manajemen Program Siaran Suara Persada di Era Digitalisasi}

Anggota Komisi Penyiaran Indonesia Daerah (KPID) Jawa Tengah, Muhammad Rofiuddin menyatakan walaupun radio merupakan media lama yang akan hilang tergerus zaman, namun pada kenyataannya radio masih tetap bisa eksis bahkan di kota besar. Bisnis radio masih cukup dapat diperhitungkan (Nirwana dan Purnamasari, $2020: 88$ )

Sebagai salah satu media komunikasi lama, Radio Persada terus berusaha mempertahankan eksistensinya di tengah masyarakat. Salah satu upaya untuk mempertahankan eksistensi tersebut adalah dengan melakukan adaptasi di era digital. Penelitian Nirwana dan Purnamasari (2020 : 88) menyimpulkan bahwa radio akan tetap eksis jika mengikuti perkembangan zaman. Radio akan mampu bertahan jika dapat didengar tidak hanya dengan cara kuno tetapi juga bisa didengarkan secara streaming melalui website. Nirwana dan Purnamasari juga menyatakan bahwa eksistensi radio akan tetap eksis jika memiliki ciri khas, produsernya kreatif dan inovatif, penyiarnya mampu menghadirkan kenyamanan dan konten acaranya yang menarik. 
M Ade Zaenury (2018 : 3) menyimpulkan hal yang sama bahwa radio harus melakukan terobosan baru untuk mempertahankan eksistensinya sehingga siarannya sampai kepada masyarakat. Radio perlu memanfaatkan jaringan internet sehingga dapat menjangkau sebagian besar masyarakat dan dapat didengarkan kapan pun dan dimana pun. Radio dikatakan eksis jika radio tersebut masih diminati banyak pendengar. Yunita (2017 : 24) berpendapat bahwa radio perlu melakukan strategi program secara On Air Promotion, Off Air Promotion dan Cross Promotion untuk menarik dan mempertahankan banyak pendengar agar tidak berpindah ke saluran lain. Menurutnya program siaran harus diproduksi dengan mempertimbangkan konten yang sedang diminati masyarakat dan berkaitan dengan topik-topik yang sedang hangat dibicarakan. Selanjutnya, penggunaan komunikasi dua arah juga merupakan nilai tambah dari sebuah radio. Lebih menarik lagi jika komunikasi dua arah tersebut dilakukan melalui berbagai saluran seperti telepon, SMS, dan media sosial seperti Facebook dan Twitter.

Rafardhan Irfan (2015: 8) berpendapat untuk mempertahankan eksistensinya radio dapat melakukan strategi internal dan eksternal dengan cara melakukan ekspansi radio dan menjadikan radio tersebut sebagai radio yang berjaringan dengan radio lain. Manajemen siaran program Suara Persada di Radio Persada Blitar sedikit banyak memiliki kemiripan dengan penelitian-penelitian pada radio di daerah lain. Secara umum manajemen siaran dalam program Suara Persada dibagi menjadi 4 tahap, yaitu:

\section{Planning (Perencanaan)}

Perencanaan merupakan suatu proses pembuatan alur atau tahapan suatu kegiatan untuk mencapai tujuan dengan membuat beberapa pilihan terbaik (Nandi dan M Nur, 2019 : 29 ). Perencanaan program Suara Persada sebelum mengudara dilakukan secara matang untuk meminimalisir atau menghilangkan kesalahan saat mengudara. Hal ini juga dilakukan untuk memantapkan konsistensi kegiatan seluruh crew dalam mencapai tujuan serta untuk melakukan monitoring kemajuan program

Perencaan program dilakukan oleh seluruh pihak terkait seperti kepala divisi penyiaran, reporter dan announcer. Kepala divisi penyiaran bertugas memimpin jalannya rapat serta menentukan issue, reporter bertugas untuk memberikan dan 
melaporkan issue dan announcer bertugas untuk menyampaikan issue tersebut kepada audience. Radio Persada juga memiliki karyawan yang bersifat multitalen yang dapat merangkap dua pekerjaan sekaligus. Sebagai contoh, seorang karyawan bisa bertindak sebagai reporter sekaligus announcer.

Perencanaan program Suara Persada diadakan dalam dua jenis rapat. Rapat pertama disebut rapat insidental, yaitu rapat yang dilakukan secara tidak terikat waktu, namun disesuaikan dengan kebutuhan program yang akan disiarkan. Rapat kedua disebut rapat rutin, yaitu rapat yang diadakan secara terikat waktu yakni setiap dua minggu sekali dengan agenda utama pembahasan program dan evaluasi.

Perencanaan program Suara Persada dimulai dengan pencarian serta pemilihan issue. Issue yang dipilih oleh Radio Persada adalah issue yang dinilai paling penting dan paling bermanfaat bagi masyarakat. Setelah issue ditetapkan kemudian dilanjutkan dengan pencarian berita terkait. Para reporter akan mencari berita dengan topik issue yang telah disepakati kemudian menyusunnya ke dalam sebuah laporan berita hingga siap diudarakan. Saat mengudara, berita atau informasi akan selalu dipantau oleh dewan pengawas.

\section{Organizing (Pengorganisasian)}

Pengorganisasian adalah suatu kegiatan mengatur atau mengkoordinir segala tugas, tanggung jawab dan otoritas setiap anggota dalam organisasi (Winardi, 2003 : 34). Pengorganisir tertinggi di Radio Persada Blitar dipegang oleh Direktur Utama. Direktur Utama bertugas menentukan segala kebijakan yang berkaitan dengan radio. Di bawah Direktur Utama Radio Persada Blitar, terdapat beberapa Kepala Divisi yang bertugas di bagian Penyiaran, Pemberitaan, Teknik dan Marketing. Kepala Divisi Penyiaran bertugas mengatur jalannya penyiaran seperti jadwal on air, penentuan program dan penentuan announcer. Kepala Divisi Pemberitaan bertugas mengkoordinasi para reporter yang bertugas mencari berita. Kepala Divisi Teknik bertugas mengatur alat-alat yang dibutuhkan selama proses pemyiaran serta melakukan perawatan teknis, sedangkan Kepala Divisi Marketing bertugas mengatur jalannya periklanan atau kerja sama antara radio dengan perusahaan iklan terkait. Kepala Divisi membawahi beberapa staff yang bekerja sesuai dengan bidang yang menjadi tanggung jawabnya. 
Radio Persada Blitar memiliki gatekeeper yang bertugas menerima dan menyeleksi informasi atau berita sebelum diudarakan. Peran gatekeeper sangat penting bagi suatu media karena tanggung jawabnya menyaring berita yang masuk, memastikan berita tersebut benar dan di dapat dari sumber terpercaya kemudian meneruskannya kepada announcer untuk disiarkan. Selain gatekeeper Radio Persada Blitar juga memiliki Dewan Pengawas. Seorang pengawas berasal dari Pemerintah Daerah dan seorang lagi dari kalangan profesional yang diambil dari Dewan Pers atau Institusi Penyiaran yang berwenang. Dewan Pengawas Radio Persada FM berasal dari Permerintah Daerah dipilih langsung oleh DPRD Kabupaten Blitar dan bertugas mengawasi jalannya penyiaran apakah telah sesuai dengan peraturan yang berlaku atau tidak.

\section{Influencing}

Influencing merupakan suatu kegiatan yang berkaitan dengan cara seorang pemimpin atau manager mengarahkan dan mempengaruhi orang-orang di bawahnya untuk bekerja seefektif dan seefisien mungkin (Kreitner dan Cassidy, 2012 : 147). Di Radio Persada Blitar tugas managerial ini dapat dilihat saat rapat insidental atau rapat rutin. Kepala Divisi sebagai manager program selalu mengarahkan dan membagi tugas bawahannya secara jelas sehingga tugas pokok dan fungsi pekerjaan bawahannya dapat terealisasi dengan baik. Selain itu, Kepala Divisi juga bertindak sebagai motivator sehingga para bawahannya selalu terdorong untuk melakukan pekerjaan semaksimal mungkin demi terwujudnya tujuan yang telah ditetapkan.

\section{Controling (Pengawasan)}

Controling merupakan suatu kegiatan memonitor atau mengawasi jalannya suatu proses apakah sudah sesuai dengan perencaan atau tidak (Manullang, 2013 : 313). Jika proses ternyata tidak berjalan sesuai rencana, maka manager harus segera mengambil tindakan agar penyimpangan tidak berjalan terlalu jauh dari perencanaan sehingga mengganggu tercapainya tujuan. Controling juga dilakukan untuk mengukur sejauh mana proses telah berlangsung, serta membandingkan capaian saat ini dengan capaian di masa lalu. Controling juga digunakan sebagai alat ukur perbaikan perencanaan di masa depan (Manullang, 2013 : 313). 
Controling di Radio Persada Blitar dilakukan oleh Badan Pengawas. Badan Pengawas adalah badan netral yang bertugas mengawasi jalannya penyiaran. Di Radio Persada Blitar Dewan Pengawas terdiri dari 1 orang dari pihak Pemerintah Daerah dan 1 orang lagi merupakan seorang profesional yang diambil dari Dewan Pers atau Institusi Penyiaran yang berwenang. Badan Pengawas memiliki tugas merumuskan kebijakan umum dan pengawasan di bidang penyelenggaraan radio, pengendalian kegiatan serta pembinaan dan pelaksanaan administrasi serta sumber daya radio.

Radio Persada dalam proses managemen program Suara Persada menetapkan untuk tidak hanya mengandalkan saluran udaranya saja tetapi juga menggunakan saluran streaming serta media sosial utamanya Facebook dan Instagram dalam menyampaikan informasi atau berita kepada masyarakat. Radio Persada mempertahankan sistem penyiaran yang sudah baik dan cocok, sekaligus terus melakukan peembenahan dan pembaruan sistem penyiaran untuk mendapatkan sistem penyiaran yang lebih baik lagi. Radio Persada masih menggunakan sistem komunikasi dua arah yang memungkinkan para pendengarnya berinteraksi secara aktif melalui telepon, pesan singkat dan pesan melalui media sosial Whatsapp, Facebook atau direct message $(D M)$ di Instagram. Komunikasi dua arah ini dipertahankan karena terbukti efektif untuk mengukur tingkat keaktifan pendengar terhadap informasi yang diberikan radio (Harapan dan Syarwani, 2014 : 2)

Radio Persada terus berusaha menarik perhatian dan mendekatkan diri dengan masyarakat dengan terlibat langsung dalam permasalahn yang dihadapi masyarakat. Radio Persada berupaya membantu dan memberikan solusi atas pengaduan masyarakat berkaitan dengan infrastruktur, pelayanan, kebijakan serta himbauan pemerintah daerah Kabupaten Blitar. Tidak hanya kepada masyarakat, Radio Persada juga membantu pemerintah daerah Kabupaten Blitar dalam penyampaian segala informasi terkait kebijakan, peraturan dan hal-hal yang berhubungan dengan pemerintahan.

Program Suara Persada merupakan program yang terbukti efektif menjangkau masyarakat. Hal ini ditunjukkan dengan peningkatan jumlah pendengar siaran Suara Persada dari hari ke hari (Nasution, 2010). Beberapa faktor yang memungkinkan terjadinya peningkatan jumlah pendengar ini adalah 
kontennya yang bersifat local dan sangat informative yang dibalut dalam kemasan yang serius tetapi santai, serta banyaknya saluran media yang digunakan sehingga memudahkan masyarakat mengakses siaran ini melalui media yang mereka miliki dan gemari. Meningkatnya antusiasme masyarakat untuk mengakses program Suara Persada, akan meningkatkan jumlah iklan komersil yang masuk ke Radio Persada. Pada akhirnya peningkatan iklan yang notabene adalah peningkatan penghasilan ini akan mampu mendorong pengembangan infrastuktur dan sumber daya, meningkatkan kesejahteraan pegawai dan akan memicu kreativitas mereka dalam menyajikan program-program bermanfaat lainnya.

\section{KESIMPULAN}

Program Siaran Suara Persada adalah program unggulan Radio Persada yang telah disiarkan sejak tahun 2018 dan terbukti tetap eksis di era digitalisasi sekarang ini. Beberapa faktor yang memungkinkan eksistensi Program Suara Persada tetap bertahan antara lain adalah; 1) konten program siarannya yang mengutamakan informasi dan berita lokal serta reportase langsung yang dikemas serius tetapi santai, 2) Radio Persada menyelipkan program citizen journalism dalam program Suara Persada yang memungkinkan masyarakat berperan serta memproduksi dan membagikan informasi atau berita dan tidak hanya menjadi penerima informasi saja, 3) Radio Persada melakukan manajemen program yang mengikuti perkembangan zaman. Manajemen tersebut meliputi kegiatan Planning, Organizing, Influencing dan Controling, 4) Radio Persada tidak hanya mengandalkan saluran udaranya dalam menyiarkan program-programnya kepada masyarakat, tetapi juga menggunakan saluran streaming serta memanfaatkan media sosial Facebook dan Instagram, 5) Radio Persada mempertahankan sistem komunikasi dua arah yang memungkinkan para pendengarnya berinteraksi secara aktif melalui telepon, pesan singkat, pesan Whatsapp, Facebook atau direct message (DM) di Instagram.

\section{DAFTAR PUSTAKA}

Andika Rizky. 2018. Strategi Komunikasi Pemasaran Radio Suara Surabaya dalam Mempertahankan Eksistensinya. Thesis. Surabaya (ID) : Universitas 17 Agustus 1945 
Asyari, Hasan Oramahi. 2012. Jurnalistik Radio : Kiat Menulis Berita Radio. Jakarta: Erlangga

Bungin Burhan, 2001. Metodologi Penelitian Kualitatif Aktualisasi Metodologis ke Arah Ragam Varian Kontemporer. Jakarta: Rajawali Pers.

Diah Andayani. 2017. Peran Jurnalisme Warga (Citizen Journalism) Berbasis Santri Sebagai Penyeimbang Komunikasi Keagamaan Lokal Kediri. Jurnal Mediakita. Vol 1 (2). 141 - 155

Edi Harapan, Syarwani Ahmad. 2014. Komunikasi Antarpribadi: Perilaku Insan dalam Organisasi Pendidikan. Depok: PT Rajagrafindo Persada

Firza Rizky Perdana. 2016. Upaya Paduka FM dalam Mempertahankan Eksistensi Fungsi Sosial Radio di Era Konvergensi Media. Thesis. Purwokerto (ID) : Institut Agama Islam Negeri Purwokerto.

Ghesilia Gianty. 2019. Manajemen Prambors Media di Era Digital. Thesis. Tangerang (ID) : Universitas Multimedia Nusantara

Hasibuan, Malayu. 1990. Manajemen Sumber Daya Manusia dan Kunci Keberhasilan. Jakarta: Haji Masagung

Kusumaningrat, Hikmat. 2005. Jurnalistik, Teori dan Praktis. Bandung: PT Remaja Rosdakarya

Laurence A. Manullang. 2013. Teori Manajemen Komprehensif Integralistik. Jakarta: Salemba Empat

Lexy J, Moleong. 1996. Metode Penelitian Kualitatif. Bandung: Remaja Rosdakarya

M Ade Zaenury. 2018 Pemanfaatan Radio Streaming Kiss Fm dalam Menjaga Eksistensi Pendengar di Kota Medan. Skripsi. Medan (ID) : Universitas Sumatra Utara.

Masduki. 2001. Jurnalistik Radio: Menata Profesionalisme Reporter dan Penyiar. Yogyakarta: LKiS Yogyakarta.

Miles, B. Mathew dan Michael Huberman. 1992. Analisis Data Kualitatif Buku Sumber Tentang Metode-metode Baru. Jakarta: UIP.

Morissan. 2009. Manajemen Media Penyiaran. Jakarta: Kencana Prenada Media Group.

Mufid, Muhamad. 2005. Komunikasi dan Regulasi Penyiaran. Jakarta: Prenada Media

Nandi dan Nur, D. 2009. Pengantar Perencanaan Wilayah. Jurusan Pendidikan Geografis UPI

Nasution, Ardiansyah. 2010. Strategi Radio Prambors Dalam Upaya Mempertahankan Pendengaran Siaran Putus Sama Nataya Di Prambors Yogyakarta. Skripsi. Fakultas Dakwah UIN Kalijaga.

Prilani. 2010. Radio Kampus. Yogyakarta: STAIN Kediri 
Puspa Nirwan dan Oktaviana Purnamasari. 2020. Komunikasi Siaran Radio untuk Mempertahankan Budaya Betawi di Era Digital. Jurnal Ilmu Komunikasi Politik dan Komunikasi Bisnis Universitas Muhammdiyah Jakarta. Vol 4 (1). $83-91$

Rakhmat, Jalaludin. 1984. Teori-Teori Komunikasi. Bandung: Remaja Rosdakarya

Ria Yunita. 2017. Strategi Komunikasi Pemasaran dalam Mempertahankan Eksistensi Radio Dangdut Terdepan di Jakarta (Studi Kasus Eksistensi Radio Cbb 105,4 FM). Jurnal Komunikasi. Vol 8 (1). 24-32

Ririn Nurmawati. 2020. Eksistensi Radio Ramayana 98,8 FM di Era Teknologi Modern dalam Penyampaian Pesan Dakwah Kota Metro. Skripsi. Lampung (ID) : Institut Agama Islam Negeri Metro Lampung

Riswandi. 2009. Dasar-Dasar Penyiaran. Yogyakarta: Graha Ilmu.

Siti Nur Rachmawati. 2019. Strategi Manajemen Siaran Radio Komunitas dalam Mempertahankan Eksistensi Radio (Studi Deskriptif Kualitatif Strategi Manajemen Siaran Radio Saka FM Yogyakarta dalam Mempertahankan Eksistensi Radio Periode 2018). Skripsi. Yogyakarta (ID) : Universitas Mercu Buana Yogyakarta.

Rafardhan Irfan. 2015. Strategi Radio Silaturahmi AM 720 Cibubur Bekasi dalam Mempertahankan Eksistensinya Sebagai Media Dakwah. Thesis. Semarang (ID) : UIN Walisongo Semarang

Robert Kreitner and Charlene Cassidy. 2012. Management. Chengange Learning

Siti Nur Rachmawati. 2019. Strategi Manajemen Siaran Radio Komunitas dalam Mempertahankan Eksistensi Radio (Studi Deskriptif Kualitatif Strategi Manajemen Siaran Radio Saka FM Yogyakarta dalam Mempertahankan Eksistensi Radio Periode 2018). Skripsi. Yogyakarta (ID) : Universitas Mercu Buana Yogyakarta.

Winardi. 2003. Teori Organisasi dan Pengorganisasian. Divisi Buku Perguruan Tinggi. Jakarta: PT Raja Grafindo Perkasa.

\section{Sumber Internet :}

Kbbi.web.id 